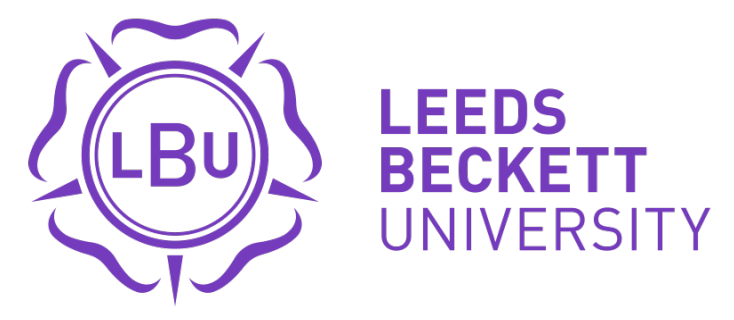

Citation:

Lofthouse, RM and Greenway, C and Davies, P and Davies, D and Lundholm, C (2020) Pre-service teachers' conceptions of their own learning : does context make a difference? Research Papers in Education. ISSN 1470-1146 DOI: https://doi.org/10.1080/02671522.2020.1767181

Link to Leeds Beckett Repository record:

https://eprints.leedsbeckett.ac.uk/id/eprint/6722/

Document Version:

Article (Accepted Version)

This is an Accepted Manuscript of an article published by Taylor \& Francis in Research Papers in Education on 01 June 2020, available online: http://www.tandfonline.com/10.1080/02671522.2020.1767181

The aim of the Leeds Beckett Repository is to provide open access to our research, as required by funder policies and permitted by publishers and copyright law.

The Leeds Beckett repository holds a wide range of publications, each of which has been checked for copyright and the relevant embargo period has been applied by the Research Services team.

We operate on a standard take-down policy. If you are the author or publisher of an output and you would like it removed from the repository, please contact us and we will investigate on a case-by-case basis.

Each thesis in the repository has been cleared where necessary by the author for third party copyright. If you would like a thesis to be removed from the repository or believe there is an issue with copyright, please contact us on openaccess@leedsbeckett.ac.uk and we will investigate on a case-by-case basis. 


\title{
Pre-service teachers' conceptions of their own learning: does context make a difference?
}

\author{
Rachel Lofthouse ${ }^{1}$, Celia Greenway ${ }^{2}$, Peter \\ Davies $^{2,4}$, Dan Davies ${ }^{3} \&$ Cecilia Lundholm ${ }^{4}$ \\ ${ }^{1}$ Leeds Beckett University, ${ }^{2}$ University of \\ Birmingham, ${ }^{3}$ University of Bath, ${ }^{4}$ Stockholm \\ University
}

Corresponding author: Professor Peter Davies, School of Education, University of Birmingham, Edgbaston, Birmingham B15 2TT, United Kingdom. Email address: p.davies.1@bham.ac.uk 


\begin{abstract}
We present an analysis of pre-service teachers' (PSTs) conceptions of their own learning, focusing on relationships between where PSTs learn and conceptions of their own learning. Our data come from in-depth interviews carried out over a six-month period with PSTs on different routes into teaching. We identify four components of learning to teach: beliefs about knowledge for teaching and the focus, timing and selfdetermination of reflection. We found weak relationships between PSTs' conceptions and their route into teaching (led by a school or university) and stronger relationships between conceptions of their own learning and their experience of mentoring in school.
\end{abstract}

\title{
Keywords
}

Routes into teaching; conceptions of teacher learning; mentoring; teacher reflection; phenomenography; variation theory.

\section{Acknowledgements}

We wish to thank the institutions and pre-service teachers participating in this research. We are grateful for helpful suggestions received from two anonymous reviewers and participants in the biennial conference of the European Association for Research in Learning and Instruction, Tampere, $2^{\text {th }}$ August- $2^{\text {nd }}$ September 2017, for helpful comments on earlier drafts of this paper. We are grateful to anonymous referees for their very helpful comments which have helped in the preparation of this paper.

\section{Funding}

This research did not receive any specific grant from funding agencies in the public, commercial, or not-for-profit sectors.

\section{Statement regarding conflict of interest}

The authors are not aware of any conflict of interest relating to this paper.

Paper length including references but excluding tables: 9114 words 


\section{Introduction}

Policy makers and researchers have asserted that where pre-service teachers learn affects how they learn, which in turn affects what they learn. These assertions have generally focused on the relative roles of higher education institutions (HEIs) and schools in the experience of learning to teach. This line of reasoning has been evident in criticism of programmes of 'teacher certification' in the US (e.g. Ballou and Podgursky 1998) and advocacy of school-based apprenticeship in 'effective practice' for pre-service teachers (PSTs) in England (Gove, 2010; Department for Education, 2016). It has also underpinned arguments for school-university partnerships in teacher education (e.g. Furlong et al. 1994) and criticism of an apprenticeship model of preservice teacher education (e.g. Hordern 2014; McIntyre, Youens \& Stevenson, 2019). Some researchers (e.g. Gilroy, 1993; Edwards, Gilroy and Hartley, 2002) have argued that whilst Higher Education (HE)-led initial teacher education encourages learning through deep reflection, school-led preparation for teaching encourages adoption of received practices that are perceived as 'what works' within particular contexts. However, research in the US and the Netherlands has found it difficult to find associations between where Pre-service teachers (PSTs) learn and the outcomes of preservice teacher education (PSTE) (Boyd et al., 2006; Buitink, 2009). Researchers have noted considerable variation between different school-based routes in the US (Humphrey and Wechsler 2007) and also between different HE- based routes in the UK (e.g. Wright and Bottery, 1997; Douglas, 2012; Authors [1]). This study responds to earlier calls (e.g. Gelfuso and Dennis, 2014) for more research into the ways in which learning environments for PSTs influence their learning (e.g. through the nature of reflection).

We use a phenomenographic/variation theory (PVT) approach in this research. This approach promises new insights into how PSTs learn and relationships between this learning and the contexts in which it occurs. We base this judgement on three fundamental aspects of PVT: (i) it treats learning (to become a teacher) as directed by conception of their learning; (ii) it regards conceptions as context dependent; (iii) it provides a systematic procedure for identifying qualitative differences between conceptions. We believe that this combination of attributes offers the prospect of a new view of PSTs' learning which will be useful for practice and policy. As far as we are aware, PVT has not been used previously to address the problem of the relationship between PSTs' learning and the contexts in which they learn.

We exploit the variation created by recent policy on pre-service teacher education in England and Wales. Using in-depth qualitative interviews, we compare PSTs who have been following different HE-based routes in England and Wales and PSTs who have been following school-led routes in England. This is not a comparison between PSTE in HEIs and PSTE in schools. PSTs on HE-led routes in England and Wales spend a large proportion of their time in schools and most PSTs on school-led routes also 
experience some input from HEIs. Our study examines whether the shift from programme leadership by HEIs to programme leadership by schools (and the related shift in the balance of these programmes) has consequences for the nature of PSTs' experience. We examine change in their accounts of how they have been learning near the start and towards the end of these programmes. These comparisons provide insight into the way that the character of their programme of PSTE has shaped how they have been learning. The results of this study bear upon policy and practice in countries (such as the US and the Netherlands) where debate focuses attention on the relative roles of HEIs and schools in PSTE.

Since PVT has not previously been used to examine PSTs' conceptions of their own learning the next section briefly reviews insights from other perspectives. We use this review in our discussion to position insights from PVT within the field. In Section Three we outline the PVT approach adopted in this research. This section explains how we draw upon recent developments in PVT that we believe are salient to researching conceptions of a complex phenomenon such as learning to become a teacher. Section Four describes the design, data collection and analysis in the study. Section Five reports the results which are discussed in Section Six. The final section concludes with a consideration of some limitations and implications of the study.

\section{PSTs' conceptions of their own learning: earlier evidence}

We present this brief summary in four sections to reflect emphases in the existing literature. The literature on approaches to studying and learning (ASL) is directly concerned with teachers' thinking and practice in their own learning. The later subsections examine the roles of epistemological beliefs, self-determination and the social context of learning. We include some references to teachers' conceptions of students' learning as this is more extensive than the literature on PSTs' conceptions of their own learning.

\subsection{Approaches to studying and learning}

Research on ASL was prompted by qualitative research revealing distinct conceptions which direct students' intention when learning in different contexts (Marton \& Säljö, 1976). A deep approach to learning is a search for underlying meaning and adopts a holistic approach to making sense of new data and situations. A surface approach to learning focuses on acquiring knowledge of the details, and accumulating facts, figures and opinions rather than striving for the big picture. Subsequent work added a third, achieving, approach which focused on what is needed to pass the course. Research in this field suggests that: each approach is characterised by several dimensions (Tait, Entwistle and McCune 1998); an individual learner's ASL will exhibit something of the characteristics of different approaches to learning (Kember er al. 1995); learners may have a disposition to adopt one of these approaches rather than the others (Entwistle and McCune 2013); the definition of different ASL may 
vary by cultural context (Dahlin and Watkins 2000); and the nature of the learning environment affects the likelihood that students will adopt one ASL rather than another (Trigwell, Prosser and Waterhouse; 1999; Authors [2]).

Researchers have examined the scope for PSTE to change PSTs' approaches to learning. Van Petegem, Donche and Vanhoof (2005) found that PSTs reporting a strong meaning orientation in their learning were also more likely to report a preference for creating constructivist learning environments for their students. However, interventions that have been designed to create learning environments that encourage PSTs to adopt a deep approach to their learning (Gordon and Debus, 2002; Struyven et al., 2006) have yielded disappointing results. Increasing PSTs' disposition to understand through a deep approach to learning has proved very challenging.

\subsection{Personal epistemology}

Chan and colleagues (Chan, 2003; Chan and Elliott, 2004; Cheng et al., 2009) analysed new teachers' epistemological beliefs using a tool adapted from Schommer (1994). This tool distinguished between beliefs about pedagogic knowledge according to whether they (i) treat knowledge as certain or uncertain (ii) treat knowledge as immutable or changing; (iii) defer to authority; and (iv) whether they treat achievement as a function of effort or innate ability. These studies reported associations between epistemological beliefs and approaches to learning. A belief that knowledge is certain and deferral to authority were positively associated with a surface approach to learning (focusing on details of particular practices rather than seeking to understand principles in relationships between teaching and learning). Some (e.g. Chan 2011) have claimed that epistemological beliefs predict approaches to learning and teaching. However, a longitudinal study by Sing Chai, Teo and Beng Lee (2009) reported that whilst PSTs in Singapore became more likely to express a view of knowledge as uncertain and were less likely to defer to authority, they also became more likely to believe that academic progress reflected innate ability and more likely to favour 'teaching as transmission'.

\subsection{Self-determination and self-regulation}

Self-determination (Ryan \& Deci, 2000) involves setting goals for learning, whilst selfregulation focuses on self-direction towards a goal. Both have been positively associated with adopting a deep approach to learning (Heikkilä \& Lonka, 2006; Kyndt, et al., 2011). Whilst these two ideas are somewhat contiguous, our literature review did not locate direct references to the relationship between self-determination and PSTs' conceptions of their learning. We did, however, note references (such as Yau 1996), to goal-setting in which the role of the PST relative to the role of the mentor was highlighted as an important issue. We located rather more studies of PSTs' selfregulation in learning (see for example, Kremer-Hayon and Tillema 1999) than their 
self-determination. Oosterheert, Vermunt and Denessen (2002) developed an instrument to measure PSTs' self-regulation. They reported that self-regulated learning and reliance on external guidance were associated with constructive learning and interpreted 'broad use of a mentor' and 'discussion at school' as self-initiated activities. They also noted potentially harmful effects on PSTs' learning arising from 'avoidance strategies' and pre-occupation when confronted with challenges.

\subsection{Conceptions of teacher learning in a social context}

Cochran-Smith and Lytle's (1999) categorisation of knowledge for teaching has been widely used to frame subsequent research (see for example Colucci-Gray and Fraser, 2008; McLeskey and Waldron, 2004; Conway et al., 2009; Goodnough, Pelech and Stordy, 2014). Cochran-Smith and Lytle (1999) distinguished between 'knowledge for practice', 'knowledge in practice' and 'knowledge of practice'. A conception of 'knowledge for practice' suggests that knowledge about teaching is generated by academics and transmitted to new teachers who have a task of applying this knowledge in their practice. A conception of 'knowledge in practice' suggests that knowledge about teaching is located in practice in schools and that new teachers gain access to this knowledge by becoming part of that practice: observing and working alongside experienced teachers and reflecting on their own experience of becoming embedded in that practice. A conception of 'knowledge of practice' positions the teacher as a researcher of the local environment provided by their school. In this view (Cochran-Smith and Lytle, 1999, 250), teachers "generate local knowledge of practice by working within the contexts of inquiry communities to theorize and construct their work and to connect it to larger social, cultural, and political issues".

This suggests that PSTs' sense of the social context (and HEI/school relationships) in which they are learning to teach will shape their understanding of their own learning. They may treat either the HEI or the school as the prime location of expert knowledge or they may treat expert knowledge as in the process of discovery: a process in which they may become a partner. The differences highlighted in the previous three sections are necessarily embedded in these different views of the social context of learning to teach. This raises, but does not answer, the question of how PSTs' sense of the social context is affected by the context in which they experience when learning to teach.

\section{The perspective on PSTs' understanding of their own learning used in this study}

PVT has brought a distinctive perspective to bear on the study of conceptions. One important belief is that the way in which individuals see the world depends on the context in which they are experiencing it. This means that conceptions should not be regarded as stable or fixed. Marton and Pong (2005) refer to this instability as 'intercontextual shifts' when showing how individuals may express a different conception 
of price according to the type of product or service. The development of PVT evidence of conceptions of price also shows how the form of a problem posed to students affects the dimensions of conceptions that are revealed (Authors, [3]). The effect of context on variation in conception is important for this study given our interest in the way that PSTs learn in different contexts.

PVT also makes distinctive claims about the structure of conceptions. These claims have been extended as Variation Theory has developed within the phenomenographic tradition to focus on change in understanding and the implications of this change for teaching. In the following account we exemplify the reasoning using the example of conceptions of price. Using an example shows how principles work in practice and Marton (2015, 103) chose this example to explain the structure of conceptions in terms of an 'outcome space' with 'dimensions of variation' (Table 1). Each dimension of variation is an aspect of the phenomenon (Marton and Booth, 108) that a learner becomes aware of when they experience variation in that dimension (e.g. in the case of Figure 1 they might be aware of different levels of demand). Within each dimension $v$ indicates awareness of variation in that dimension and $i$ (for invariant) indicates no awareness of variation in that dimension. Each conception is distinguished from others by the way in which it recognises variation in dimensions of variation.

\section{Table 1 Dimensions of variation in conceptions of price}

\begin{tabular}{lcccc}
\hline \multirow{2}{*}{ Conception } & \multicolumn{3}{c}{ Dimensions of variation } \\
\cline { 2 - 5 } & $\begin{array}{c}\text { Attributes of } \\
\text { the product }\end{array}$ & Demand & Supply & Price \\
\hline 1 Price depends on attributes of the commodity & $v$ & $i$ & $i$ & $v$ \\
2 Price depends on people's willingness to buy & $i$ & $v$ & $i$ & $v$ \\
3 Price depends on how much there is to buy & $i$ & $i$ & $v$ & $v$ \\
4 The price is a function of willingness to buy & $i$ & $v$ & $v$ & $v$ \\
and how much there is to buy & & & & \\
\hline Source: Marton $(2015, p .103)$ &
\end{tabular}

The four conceptions in Table 1 are presented as a hierarchy (in so far as the most complex conception (4) incorporates conceptions 2 and 3). The idea that conceptions are nested in this way is an important theme in phenomenographic analysis. Marton and Booth $(1997,107)$ offered two justifications for this position: (i) that more complex conceptions recognised more dimensions of variation; and (ii) one conception may be regarded as more complex than another on the basis of a value judgement about the behaviours that are predicated on either conception. Others (Åkerlind, 2003; Pang, 2003) justified an assumption of hierarchy on the basis that conceptions were logically related. In Table 1 it is not possible to distinguish between conceptions 1, 2 and 3 on 
the basis of the number of dimensions of variation. However, conceptions 2 and 3 are logically related to conception 4 which recognises more dimensions of variation than any of the other 3 conceptions.

Other studies (e.g. Authors [3]; Durden, 2018) have revealed other dimensions of variation in conceptions of price by examining understanding of related phenomena. Pang and Marton (2003) exposed variation in understanding of the consequences of changes in price on demand and supply ${ }^{1}$. In the light of these studies we might retitle Table 1 'Dimensions of variation in conceptions of what affects pric'e. Each of these studies revealed a structure of conceptions that can be presented in a table that is similar to Table 1. Considered together, these studies tell us more about conceptions of price than any one study. Whilst each study reveals conceptions of a distinct phenomenon, collectively they tell us about conceptions of a meta-phenomenon: price. This prompts the question 'how are the conceptions of related phenomena connected?

The brief review of other literature in the previous section has indicated that learning to become a teacher is a complex phenomenon. In this study we will treat learning to become a teacher as a 'meta-phenomenon' and that we can view constituents of this phenomenon as phenomena in their own right. In the language of PVT, we can examine dimensions of variation in conceptions of each constituent phenomenon. When we look at the meta-phenomenon of learning to become a teacher we then treat each of the constituent phenomena as dimension of variation in conceptions of the meta-phenomenon.

Finally, variation in intention to learn has been at the heart of the PVT tradition (Pang 2003). Learning may be directed by the learner's intention to compare different ways of understanding a phenomenon (conceptions 1-4). Linder and Marshall (2003) suggest that this is the PVT perspective on reflection in learning. Moreover, intentions in learning are affected by perceptions of the context in which learning takes place (e.g. Trigwell, Prosser and Waterhouse, 1999; Authors [2]). Consequently, the context in which PSTs learn to teach may affect their learning in two ways. First, the context may draw PSTs' attention to a new way of understanding of their own learning by highlighting dimensions of variation. Those who are helping PSTS to learn may intentionally control the context to bring this about. Second, the context for learning to teach may give encouragement and space to PSTs' intentions to explore variation in ways of understanding 'learning to teach'. Alternatively, those who are helping PSTs' to learn how to teach may close down that space by expecting PSTs to conform to particular practices.

In summary, these studies suggest the following:

(1) Within a single dimension of conceptions of a phenomenon (such as factors affecting price or effects of price) there is a logical hierarchy. 
(2) Relationships between the structures of conceptions of related phenomena that may be regarded as dimensions of variation in a meta-phenomenon are matters for empirical enquiry.

(3) The problem that is posed to students may limit which dimensions of variation are brought into view, constraining the perceived scope of the phenomenon.

(4) Learning may occur as a response to experienced variation and/or as an outcome of an active search for variation.

\section{Method}

\subsection{Research design}

We addressed the following research questions:

1. What conceptions of their own learning do PSTs use to direct their development?

2. How are changes in these conceptions related to the context in which they are learning?

The first question was motivated by the need to understand ways in which PSTs understand their own learning in order to support their agency in developing as teachers. The second question was motivated by continuing debate over the type of learning environment (particularly in terms of school-led vs university-led) that is best for learning to teach (Authors, 4). We answer these two questions through a study of PSTs participating in programmes associated with three HEIs. This will not capture the full range of variation across the country and should not be interpreted as representative. The broad differences between these routes at these institutions are summarised in Table 2. On the Bachelor programme the HEI was responsible for all the taught input for PSTs. In the postgraduate programmes this input was shared between HEIs and schools. The HEI input to school-led programmes was just over a third of the HEI input on the HEI-led programmes. The second question has two strands: variation in the context experienced by different PSTs at the same point in time and variation in context experienced by the same PST during their preparation for teaching. 
Table 2 Key differences between HE-led and School-Led PSTE programmes in this study

$\begin{array}{ll}\text { Undergraduate } & \text { Postgraduate School-led } \\ \text { HEI-led } & \text { HEI-led }\end{array}$

\begin{tabular}{|c|c|c|c|}
\hline $\begin{array}{l}\text { Programme } \\
\text { purpose and } \\
\text { priorities }\end{array}$ & \multicolumn{2}{|c|}{$\begin{array}{l}\text { Set by HEI within the constraints } \\
\text { of government requirements }\end{array}$} & $\begin{array}{l}\text { Set by school within the } \\
\text { constraints of government } \\
\text { requirements }\end{array}$ \\
\hline $\begin{array}{l}\text { Recruitment of } \\
\text { PSTs }\end{array}$ & \multicolumn{2}{|c|}{$\begin{array}{l}\text { Designed and led by HEI. School } \\
\text { teachers participate in } \\
\text { interviews }\end{array}$} & $\begin{array}{l}\text { Designed and led by school } \\
\text { with some input by HEI }\end{array}$ \\
\hline $\begin{array}{l}\text { Selection of } \\
\text { school } \\
\text { placements }\end{array}$ & \multicolumn{2}{|c|}{ Determined by HEI } & Determined by school \\
\hline $\begin{array}{l}\text { Mentor } \\
\text { training }\end{array}$ & \multicolumn{2}{|c|}{ Designed and led by HEI } & Designed and led by school \\
\hline $\begin{array}{l}\text { Required } \\
\text { proportion of } \\
\text { time spent in } \\
\text { school }\end{array}$ & $\begin{array}{l}\text { minimum } 32 \\
\text { weeks on } 4 \\
\text { year } \\
\text { programme }\end{array}$ & $\begin{array}{l}\text { Minimum of } \\
24 \text { weeks (out } \\
\text { of } 36 \text { week } \\
\text { course) }\end{array}$ & $\begin{array}{l}\text { Minimum } 24 \text { weeks for } \\
\text { 'Tuition fees' School-Direct } \\
\text { route; length of time to be } \\
\text { determined school for School } \\
\text { Direct 'Salaried' route. }\end{array}$ \\
\hline $\begin{array}{l}\text { Assessment of } \\
\text { PSTs' progress }\end{array}$ & \multicolumn{2}{|c|}{$\begin{array}{l}\text { Directed by HEI which retains } \\
\text { the final judgement. Routine } \\
\text { observation and guidance } \\
\text { carried out by mentors in school } \\
\text { with oversight from HEI. }\end{array}$} & $\begin{array}{l}\text { Directed by the school which } \\
\text { makes the final judgement. } \\
\text { Routine observation and } \\
\text { guidance by mentors. May be } \\
\text { some input or advice from an } \\
\text { HEI. }\end{array}$ \\
\hline
\end{tabular}

\subsection{Participants}

The sample of interviewees is set out in Table 3. Our interviewees were selected to represent a range of Primary and Secondary ITE routes within each HEI (e.g. final year undergraduate, PGCE, PGDipEd and School Direct). Our English sample, reflecting current policy (Carter 2015), was a mixture of school-led (School Direct) and HEI-led ITE including PSTs working in different primary and secondary teaching school alliances in a range of more and less advantaged areas. The Welsh sample was entirely HEI-led. All the programmes had formative and summative assessment processes based around tasks and assignments which encourage reflection on practice. All 
programmes also included academic and professional aspects and allow successful participants to gain qualification as teachers. In reporting our data we indicate interviewee training route, institutional type and phase.

Table 3 Sample characteristics

\begin{tabular}{lllll}
\hline & & \multicolumn{2}{l}{$\begin{array}{l}\text { Research intensive } \\
\text { universities (England) }\end{array}$} & $\begin{array}{l}\text { Teaching } \\
\text { intensive } \\
\text { universities } \\
\text { Wales }\end{array}$ \\
\hline $\begin{array}{l}\text { Primary } \\
\text { postgraduate }\end{array}$ & $\begin{array}{l}\text { University- } \\
\text { based } \\
\text { School Direct }\end{array}$ & $6(5)$ & $4(4)$ & $5(5)$ \\
\hline $\begin{array}{l}\text { Secondary } \\
\text { postgraduate }\end{array}$ & $\begin{array}{l}\text { University- } \\
\text { based } \\
\text { School Direct }\end{array}$ & $7(6)$ & $2(2)$ & $5(5)$ \\
\hline $\begin{array}{l}\text { Primary } \\
\text { undergraduate }\end{array}$ & $\begin{array}{l}\text { University- } \\
\text { based }\end{array}$ & & & \\
\hline $\begin{array}{l}\text { Secondary } \\
\text { undergraduate }\end{array}$ & $\begin{array}{l}\text { University- } \\
\text { based }\end{array}$ & & & $2(0)$ \\
\hline Total & $15(13)$ & $6(6)$ & $16(12)$ \\
\hline Figures & & & \\
\hline
\end{tabular}

Figures in brackets indicate PSTs who were interviewed twice

\subsection{Interviews}

PSTs who remained on their programme were interviewed twice, with a gap of roughly six months between interviews. The semi-structured interviews focused on PSTs' recent experience and their written reflections on that experience (see Hurworth 2012). The initial question was 'what have you learned during the last four weeks?', followed by 'how did you learn this?', accompanied by probes of initial answers and a request for elaboration on whether the examples given were typical of their learning. By asking 'what have you learned?' we tried to locate the interview in PSTs' recent experience. This starting point also meant that part of the interview focused on PSTs' beliefs about the nature of knowledge that is valuable for teachers. We also asked interviewees to choose an example of their written reflections on lessons and asked them to explain why they had written about their lesson in this way. This approach to interviewing followed advice from Dahlberg, Moss and Pence (2007) and Qu and Dumay (2011) and was broadly similar to that used by Grindstaff, Cho and Anderson (2003), in contrast to the general questions (e.g. 'How would you describe what learning to teach means to you?) used by Taylor (2008). Interviews lasted between 20 and 45 minutes and were recorded using a digital recorder. The research conformed to the ethical guidance on informed consent and data storage published by the British 
Educational Research Association (BERA) (2011) and was approved by the ethical committees in each participating institution.

One of the challenges in trying to identify change in conceptions is to distinguish between: difference that is a serendipitous response to immediate circumstance associated with the interview itself, difference that reflects a change in the context in which learning has been taking place and difference that reflects a change in the conceptions that the interviewee is currently using to make sense of the phenomenon. We addressed this challenge by keeping the interviewer the same between the two interviews for each PST. However, this could mean that the interviewee was more relaxed in the second interview in so far as a rapport had developed with the interviewer (Flick, 2002). In the second interview, PSTs were also asked to comment on whether the way they had been learning had changed over the previous six months. We were then able to check our comparisons of interviewees' accounts with their testimony regarding change or stability in how they believed they were learning.

We aimed to reduce the scope for 'social desirability bias' (Krumpal, 2013): interviewers were not members of programme teams responsible for that PST; the descriptive focus of the questions did not introduce ideas about learning or prompt references to contexts for learning; and interviewees were not invited to comment on the quality of the learning environments they had experienced.

\subsection{Analysis}

Our coding of transcripts followed the holistic approach favoured by the PVT tradition (Åkerlind 2003). This approach emphasises comparison between scripts in the search for different ways in which a phenomenon (such as PSTs' learning) may be understood.

Through comparison of transcripts collected within each institution we began to identify ways in which PSTs' conceptions of their learning varied. We then met as a cross-institution team to agree a categorisation of differences and to discuss the relationship between these categories and our reading of previous research in this field. This first involved identifying dimensions of the meta-phenomenon of learning to become a teacher (e.g. in the focus of their reflection). We then treated these as phenomena in their own right and agreed upon categorical variation in conceptions of these phenomena and the dimensions of variation recognised (or not) by these conceptions. Researchers at each institution then re-analysed their scripts. This prompted a slight further revision of the categories. Anonymised coded transcripts (a $15 \%$ sample) were then shared across the institutions for reliability checks. 
Each interview was coded for each dimension we identified in PSTs' conceptions. We examined two patterns in these data. First, we used chi-squared tests to examine associations between the dimensions (using each of our 68 interviews). A Bonferroni correction was used when interpreting these data. Second, we examined patterns of change between T1 and T2 in each dimension for the 29 PSTs we interviewed at T1 and $\mathrm{T} 2$.

\section{Results}

We begin by presenting dimensions of four phenomena we observed in PSTs' accounts of their own learning (Table 4). The first phenomenon concerns beliefs about expert knowledge for teaching. The remaining three are concerned with the process of how PSTs' learn through reflection. It is conventional to speak of 'reflection' as unambiguously a 'good thing'. But PSTs clearly experienced reflection in quite different ways and one PST commented "I'd say it's, as awful as it can be doing reflections after every single lesson at times" (Secondary, HEI-led programme, Wales). For this PST, reflection appeared little more than a required activity.

There is a hierarchy in conceptions of each phenomenon in so far as the final category (e.g. 'general idea that needs to be reworked for context' in the phenomenon 'knowledge for teaching' in Table 4) incorporates awareness of variation in values for each of the categories.

Table 4 Summary of conceptions of each of four phenomena identified within the meta-phenomenon of 'learning to become a teacher'

\begin{tabular}{c|ccc} 
Knowledge beliefs & \multicolumn{3}{|c}{ Reflection } \\
\hline $\begin{array}{c}\text { Knowledge for } \\
\text { teaching }\end{array}$ & Focus & (3) & (4) \\
\hline $\begin{array}{c}\text { Personal teacher } \\
\text { knowledge }\end{array}$ & Events & In flight & Colf-determination \\
$\begin{array}{c}\text { Knowledge for } \\
\text { context }\end{array}$ & Themes & Struggle over time & Adapting \\
$\begin{array}{c}\text { Generalisable } \\
\text { ideas }\end{array}$ & Being a Teacher & & Evaluating \\
$\begin{array}{c}\text { General idea that } \\
\text { need to be } \\
\text { reworked for } \\
\text { context }\end{array}$ & & & \\
\hline
\end{tabular}


In Sections 5.1 to 5.4 we present results on conceptions of the four phenomena we identified in PSTs' conceptions of their learning (research question 1). In each case we exemplify each conception and show how they are related through dimensions of variation (in the format of Table 1). Section 5.6 examines associations between conceptions of the four phenomena. On this basis, we distinguished between an adherence conception (learning to do the right thing) and an enquiry conception (learning to find my own way). Section 5.8 presents results in relation to research question 2, examining relationships between conceptions and the contexts in which PSTs were learning.

\subsection{Phenomenon 1: Knowledge for teaching}

The first three categories (personal teacher knowledge, knowledge of context and generalizable ideas) each indicated a view of knowledge as fairly certain (Table 4). The difference between these three categories was due to beliefs about where to look for the 'right knowledge'. They exemplify three different ways of interpreting the 'what works' agenda. This is exemplified by the second example of 'personal teacher knowledge' in Table 5. The final category treated learning to become a teacher as entailing learning to deal with the complexity and uncertainty of the knowledge required for the job. Our choice of illustrative utterances in Table 5 shows how those characterised as 'general ideas that need to be evaluated and reworked for context' tended to show awareness of other values in the 'knowledge of teaching' dimension which was not apparent in utterances in the other categories in this dimension.

Table 5 Structure of conceptions of: Knowledge for teaching

Dimensions

\begin{tabular}{lcccc}
\cline { 2 - 5 } Conceptions & $\begin{array}{c}\text { Knowing } \\
\text { what is good } \\
\text { for me }\end{array}$ & $\begin{array}{c}\text { Knowing } \\
\text { what is good } \\
\text { for here }\end{array}$ & $\begin{array}{c}\text { Knowing } \\
\text { what is good } \\
\text { for } \\
\text { everywhere }\end{array}$ & $\begin{array}{c}\text { Knowing how } \\
\text { to relate } \\
\text { principles to } \\
\text { context }\end{array}$ \\
\hline $\begin{array}{l}\text { Personal teacher } \\
\text { knowledge }\end{array}$ & $v$ & $i$ & $i$ & $i$ \\
$\begin{array}{l}\text { Knowledge for context } \\
\text { Generalisable ideas }\end{array}$ & $i$ & $v$ & $i$ & $i$ \\
$\begin{array}{l}\text { General ideas that } \\
\text { need to be evaluated } \\
\text { and reworked for }\end{array}$ & $v$ & $i$ & $v$ & $i$ \\
context. & & $v$ & $v$ & $v$ \\
\hline
\end{tabular}




\section{Exemplification}

Personal teacher knowledge

Knowledge for context

Generalisable ideas

General ideas that need to be evaluated and reworked for context.
"I don't know, you know, I think it's just a personal thing, you know, different teachers teach in different ways."

"It's like every school has different circumstances and I guess teachers who have been at that school for, in surplus of 10 years, they've probably seen students like it, they've had similar situations with their classes and they have developed these strategies."

"Good ideas for teaching are floating around out there and you have to try to spot them."

"Someone who said that they thought the way in which they taught grammar, so in their explicit way, was the best way and they were very explicit and then other people that I've read about, they said, oh, it's all just implicit teaching, but I've kind of thought, no, I don't think you should just stick with one area, you should mix it and yeah, use it both ways."

"What I have come to realise this year is that a very much integrated theory and practice and you have to attend to both and sometimes one will dominate over the other, but they always have to circle round."

\subsection{Phenomenon 2: Focus}

PSTs spoke of focusing their reflection either in terms of learning what to do in specific situations (events), how to deal with themes in teaching (such as differentiation or feedback), or how they were developing as a teacher (Table 6).

The category 'reflection on events' should not be read as meaning 'reflection on critical incidents'. The examples we have classified as 'reflection on events' refer to instances where PSTs talked about the judgements that a particular piece of teaching had gone well or gone badly. It does not refer to reflection which locates a particular incident as prompting reconsideration of their understanding of a theme (such as differentiation, understanding classroom behaviour or feedback). Categorisation of reflection as focused on a theme includes reference to examples of practice and reflection on 'being a teacher' includes reference to themes and examples of practice. We did not observe reflection on being a teacher which did not refer either to a theme or specific examples. Moreover, PSTs who referred to reflection on being a teacher showed awareness of 
focusing their reflection in different ways, whilst PSTs who referred only to reflection on specific situations did not.

\section{Table 6 Structure of conceptions of: Focus of reflection}

\begin{tabular}{lccc} 
& \multicolumn{3}{c}{ Dimensions } \\
\cline { 2 - 4 } Conceptions & $\begin{array}{c}\text { Impact of single } \\
\text { teaching experience }\end{array}$ & $\begin{array}{c}\text { Understanding a } \\
\text { theme }\end{array}$ & $\begin{array}{c}\text { Understanding } \\
\text { myself as a teacher }\end{array}$ \\
\hline Events & $\mathrm{V}$ & $\mathrm{i}$ & $\mathrm{i}$ \\
Themes & $\mathrm{V}$ & $\mathrm{v}$ & $\mathrm{i}$ \\
Being a teacher & $\mathrm{v}$ & $\mathrm{v}$ & $\mathrm{v}$ \\
\hline
\end{tabular}

\section{Exemplification}

Events "Actually picking out the things that have worked well."
"Themes
you know, do this one and then wherever we are, we're going to
stop here and we're going to talk a bit and then we're going to
do a second activity which is completely, well, not completely
different but is away from that one and I've felt, through
feedback from other teachers and just looking at the kids' books,
it was clear that they were progressing at different rates, which
is perfectly natural, of course, so just thinking about how to
combat that."

Being a teacher "One of the most important things that I've learned is the amount of, what's the word, responsibility, you have as a teacher and to evaluate that and to reflect on that and not be scared by it."

\subsection{Phenomenon 3: Time spent in reflection}

This phenomenon is the timescale that the PST referred to when speaking about their learning. Some PSTs spoke chiefly of ideas coming to them whilst they were teaching or of 'knowing right then' whether their teaching had been good or bad (Table 7). Others spoke about long struggles in their learning, particularly when they spoke of learning about themes in teaching (such as differentiation or feedback) or learning about 'being a teacher'. 
Table 7 Structure of conceptions of: Time spent in reflection

\begin{tabular}{lcc} 
& \multicolumn{2}{c}{ Dimensions } \\
\cline { 2 - 3 } conceptions & Reacting in the moment & $\begin{array}{c}\text { Working things out over } \\
\text { a period }\end{array}$ \\
\hline In flight & $v$ & $i$ \\
Struggle over time & $v$ & $v$ \\
\hline
\end{tabular}

\section{Exemplification}

In flight "I had to do something quickly on the board and I used it and it worked, so it was kind of nice and I felt comfortable because that was something I was used to doing and they did understand, so it was nice."

"Like this situation that I hadn't thought would be an issue at all, so in those situations, yeah, it's very much like, okay, how can I deal with this and it's off the cuff and you try something, it might work and in this case it did."

Struggle over time "I knew I had to address it (the way the school wanted her to deal with classroom management) in a constructive way, which took a lot of processing. It would have been very tempting just to get very annoyed with them, but you can't do that because you will lose everything in your placement. I had to find a way of working things out."

\subsection{Phenomenon 4: Self-determination in reflection}

Most of the PSTs seemed to believe that they were exercising a high degree of agency in their learning, but this was frequently less evident in their more detailed descriptions of what they actually did. Our coding of self-determination (Table 8) was based primarily on PSTs' descriptions of what they did and their stories of particular examples of their learning. Limited space in Table 8 prevents us from showing how the quotations were embedded in these more detailed stories. The dimension of variation 'evaluation of the rationale for this way of teaching' indicates awareness of different ways that a way of teaching might be justified by reference to theory and evidence. 
Table 8 Structure of conceptions of 'self-determination'

Dimensions

\begin{tabular}{lcc}
\hline Conceptions & $\begin{array}{c}\text { Self-directed search for new ideas } \\
\text { or information }\end{array}$ & $\begin{array}{c}\text { Self-directed evaluation of the } \\
\text { rationale for this way of teaching }\end{array}$ \\
\hline Copying & $i$ & $i$ \\
Adapting & $v$ & $i$ \\
Evaluating & $v$ & $v$ \\
\hline
\end{tabular}

Exemplification

Copying "I think I just went in there, I just followed what the teacher said to
do for the lesson, it wasn't really me thinking"
"They're giving us ideas and things to try out"
"Well, I would give it a go, but I won't necessarily take it as truth
and keep working with it even if it doesn't work for me, I think."
"So instead of expecting people to feed me bits of information, I've
sort of gone to look for it a bit more and it's gone a lot easier."
"I think here it was very much establishing what I wanted to do in
a lesson, the activities I would be doing and the way it actually
physically worked. Whereas it is now more focused on the impact
on the learners of the lesson. At the beginning it was how I teach
and what I could do, whereas now it is how my teaching is affecting
students and the reasoning's for that."

5.5 Relationships between conceptions of knowledge for teaching and elements of reflection

We now turn to PSTs' conceptions of the 'meta-phenomenon' of their own learning in terms of conceptions of the four phenomena outlined in the previous sections. This part of the analysis makes us treat conceptions of each phenomenon as dimensions of variation of the meta-phenomenon. But since we have already seen how awareness of each phenomenon may take qualitatively different forms it does not make sense to present this analysis in binary terms of variance and invariance. We analysed relationships between conceptions of knowledge for teaching and reflection through bi-variate cross-tabulations of the values ascribed to each PST's conception of that phenomenon. For this analysis we combined 'personal teacher knowledge', 'knowledge for context' and 'generalisable ideas' on the grounds that each treated 
knowledge as certain whilst looking in different places for the source of expertise. After imposing a Bonferroni correction the Pearson Chi-squared tests of independence indicated that there was a less than $5 \%$ chance that the observed positive association between the hierarchies for focus of reflection and knowledge for learning was a random event. There was a less than $1 \%$ chance that any of the other positive associations was random. For example, 13 of the 20 interviews coded as describing their reflection as focusing on events also expressed a 'copying' approach to selfdetermination and none expressed an 'evaluating' approach. Conversely, 15 of the 23 interviews coded as expressing an 'evaluating' approach to self-determination also described their reflection on 'being a teacher'. Only 2 of these 23 spoke of the focus of their reflection simply in terms of events.

In this light we re-examined the transcripts to examine relationships within individual scripts (Table 9). We found that a group of our transcripts displayed the following combination of values (characteristics): reflection chiefly on specific events, copying, emphasis on learning 'in flight' and a certain view of knowledge. This bundle of characteristics could be labelled 'adherence' (learning to do the right thing) and is illustrated from one interview with a primary PST following an HEI-led programme:

... to ensure that they get started in the first five minutes, that they have understood the task, that they have picked their pen up, that they are sitting comfortably, that they have their book, they have all the resources they need, and they can get going.

I don't know if I've done it right, I don't know if I've done what's being expected of me, but this is my take on it.

I found myself mirroring the things she was doing because I just found that they worked so effectively.

As far as the rest of teaching practice is concerned, it's very much been suck it and see

\section{Table 9 Adherence and enquiry in PSTs' conceptions of their own learning}

\section{Conception}

Phenomena

(dimensions of 'Learning Adherence Enquiry

to become a teacher)

\begin{tabular}{lll}
\hline $\begin{array}{l}\text { Knowledge for } \\
\text { teaching }\end{array}$ & $\begin{array}{l}\text { Knowledge for teaching is } \\
\text { certain }\end{array}$ & $\begin{array}{l}\text { Knowledge for teaching is } \\
\text { uncertain }\end{array}$ \\
\hline Focus & On events & $\begin{array}{l}\text { On themes and being a } \\
\text { teacher }\end{array}$ \\
Time & $\begin{array}{l}\text { Learning in the moment ('in } \\
\text { flight') } \\
\text { Copying }\end{array}$ & $\begin{array}{l}\text { Learning as a struggle over } \\
\text { time } \\
\text { Self-determination }\end{array}$ \\
\hline
\end{tabular}


Another common bundle of values was: tending to reflect on themes or teaching as a whole, evaluating, regarding knowledge for teaching as complex and uncertain, teacher learning as long struggle. This bundle could be described as 'enquiry' (learning to make sense of teaching) as exemplified by the utterances from another secondary PST following a university-led programme:

So I kind of just wanted to try it on my own, instead of just being told, 'cause that's, I'm not going to have that for my next year, so I need to take it all into my own hands, so I did actually say, this is what I want.

I think to myself, right, okay, I can really exploit that activity, the exercise and I can use that, instead of trying to think of loads of different things, I'm now thinking I guess in teacher mode more than I was before maybe.

... (of the complexity and uncertainty of knowledge for teaching) there will be many other ways of doing it, so don't just go with your first instinct.

... (referring to written assignments) definitely, 'cause it makes you think about how you can put what you've learnt into practice.

... It's critiquing, it's analysing, criticising the literature you've found in more detail and depth and then proposing new ideas.

... (speaking of her learning) from speaking with the mentors, with other people in the cohort, from the seminar discussions, I mean, I've been to a few union conferences as well.

\subsection{Relationships between context and PST conceptions of their learning}

The PVT approach we have followed in this research suggests we should examine two ways in which contexts bear upon the way that phenomena are understood. The first of these is the way in which contexts highlight dimensions of variation. The PST literature has emphasised the importance of helping new teachers to understand knowledge for teaching in terms of working out how to relate principles to practice. However, only half of the interviews expressed this kind of understanding. Moreover, at the first interview there was no difference between PSTs following an HE-led route and PSTs on a school-led route. At this point, many of the PSTs at one HEI were experiencing a disjunction between principles and practice.

"Personally, I think most reflection and evaluation is done almost subconsciously whilst you're teaching the lesson. If something happens, you think, Ugh, I won't do that again, or, I'll do that again. It's logged in and you know it; there's no need to write it in. The writing down of it was more to appease the demands of the folder and the marking system." (PST on Bachelor of Education programme, $1^{\text {st }}$ interview) 
However, in the second interview towards the end of the course the likelihood that a PST on a school-led course expressed understanding of knowledge for teaching had radically declined, whilst for PSTs on an HE-led course that probability had strongly increased. The difference between the two routes was highly unlikely to be random (Fisher's Exact Test $p<.001$ ) not only when restricting the sample to the second interview, but also when including both interviews in the test. This difference is illustrated by the following quotations:

I think with School Direct you very much learn by having a go and watching the other teachers. For me, personally and my learning style, I learn a lot more in that classroom than I do in a lecture theatre, which is why I chose School Direct. (PST on school-led programme)

At the beginning of the course we had to write in a learning journal and at first is very much like: 'I did this... I did that...', so I have learned how to be more reflective of my practice, where I am really reflecting on it rather than just telling a story on what I did. I talk about key areas of my lessons that I want to improve on, and what went well and why they went well, rather than having that step by step of exactly what I did, which doesn't really help when I look back on it. (Primary, HE-led, Wales)

I think it's much more independent now, so it used to be that I was watching a lot more and following what they did, whereas now I'm trying to incorporate those ways into the way that I do it myself, so I think it has changed. (Secondary, HE-led England)

A similar pattern was observed in comparisons of PSTs on HEI-led and school-led routes for two of three components of reflection: time and self-determination. We found no significant difference for the focus of reflection. One possible reason for this could be that immediate evaluation of individual lessons is a dominant feature of the way reflection is encouraged on both routes. Moreover, the majority of PSTs on HEled routes described the formal written processes in place to guide their reflection as focusing on individual lessons. They regarded these processes as requiring them to focus on events.

The second way in which PVT anticipates an effect of context on conceptions of learning is through the space and encouragement that a context provides for the learner's self-direction. PSTs' comments about their way of learning being constrained by their context all referred to experiences in school.

"(in my previous employment experience) Feedback is a two way process and I don't know whether that's different in teaching, 'cause I'm older than, that's why I chose School Direct and I was a manager and for me, feedback was always very much two way, what do you think, because I got a lot from that as well and for me it surprised me that it wasn't like that in teaching." (PST on school-led route) 
"In my placement I had to find a way of working these things out without completely destroying my relationship with the school, which would have been very counterproductive". (PST on HEI-led route)

Comments like these were much more frequent amongst PSTs on school-led routes. However, a significant minority of PSTs on HEI-led routes had similar stories to tell. PSTs were particularly conscious of these constraints when they were experienced in their second placement. In addition, some PSTs spoke of being constrained by the difficulty of managing classroom behaviour. When they referred to learning about classroom management they were more likely (than when discussing pupils' learning) to view their own learning in terms of learning the 'right way' to act.

To consider implications of school context for PSTs' progress during the year of PSTE we examined change in PSTs' conceptions through simple cross-tabulations of values recorded in each dimension in the first and second interviews. In each dimension roughly half of the PSTs changed between interview 1 and interview 2, but there was no overall pattern in the direction of change for beliefs about knowledge for teaching or self-determination. The patterns of change in the focus and time of reflection are shown in Table 10.

Table 10 Change in focus and time for reflection

Focus

Interview 2

Total

\begin{tabular}{llcccc} 
& & Events & Themes & $\begin{array}{c}\text { Being a } \\
\text { teacher }\end{array}$ & \\
\cline { 3 - 5 } & & 3 & 1 & 6 & 10 \\
\multirow{3}{*}{ Interview 1} & Events & 1 & 8 & 2 & 11 \\
\multirow{2}{*}{ Total } & Themes & 3 & 0 & 5 & 8 \\
& Being a teacher & 7 & 9 & 13 & 29 \\
\hline
\end{tabular}

Time

Interview 2

Total

\begin{tabular}{lllcc}
\hline \multirow{2}{*}{ Interview 1 } & In flight & 5 & 4 & 9 \\
\multirow{2}{*}{ Total } & Struggle over time & 3 & 17 & 20 \\
\hline
\end{tabular}

The distributions of values in the focus of reflection $(p=.005)$ and in the time taken in reflection $(\mathrm{p}=.024)$ were significantly different in interview 2 compared with interview 1. PSTs were more likely to say they were focusing reflection on being a teacher and learning as a struggle over time in the later interviews. This suggests that, 
on average, PSTs had moved towards a more advanced way of learning by the end of their ITE programmes.

\section{Discussion}

This section considers the results in relation to previous phenomenographic research before reviewing the results in relation to arguments and evidence about PSTE. Early phenomenographic research on approaches to learning generated the influential literature on approaches to studying (e.g. Kember and Leung, 1998) which has been applied to the analysis of PSTE (e.g. van Petegem, Donche and Vanhoof, 2005; Struyven et al., 2006). However, these instruments (and their subscales) evolved without much further input from phenomenographic research (Kember and Leung, 1998; Entwistle and McCune, 2004). This study suggests that ideas about the structure of conceptions developed more recently in PVT (dimensions of variation and relationships between conceptions of connected phenomena) could be used fruitfully in revisiting the components of conceptions of learning.

The results from this study identified two phenomena (self-determination and beliefs about knowledge) that have featured in instruments designed to reveal approaches to study (see Entwistle \& McCune, 2004) and epistemological beliefs (e.g. Schommer 1994). However, our results have also identified focus and time as important components of reflection in learning to teach. The importance of reflection in teacher education is widely asserted, but this study draws attention to variation in PSTs' breadth of focus when they reflect on their experience. So far, researchers have struggled to find causal evidence indicating that the design of learning environments has encouraged PSTs to adopt a deep approach to their studying. PVT argues that learning environments must highlight variation in the dimensions of a phenomenon that are critical to the development of a more powerful conception and more powerful learning. The qualitative distinctions identified in the results could stimulate further work that helps teacher educators to identify and act upon those critical dimensions.

Previous research has examined associations between some of the phenomena within the meta-phenomenon of learning to become a teacher that have been identified in this study. For example, Chan (2003) reported associations between PSTs' epistemological beliefs and their approaches to learning. This study suggests it may be useful to simultaneously consider a broader set of phenomena: knowledge for teaching (epistemological beliefs and the roles of focus, time and self-determination in reflection). This study also identifies dimensions of variation within these phenomena that will be critical to developing more powerful ways of learning to teach. It also provides some support for the suggestion (e.g. Edwards et al., 2002; Hordern, 2014) that PSTs may approach their learning to become teachers in terms of either 'adherence' (an apprenticeship model) or 'enquiry' (an occupational 
professionalism model). However, we only found an indication in this small-scale study that there was a modest association (Fisher's exact test, $\mathrm{p}=0.53$ ) between the overall conception of their learning and whether PSTs were following a school-led or a university-led programme. Variation in PSTs' conception of their learning occurred within each type of programme suggesting that it was the nature of their experience within each school that was the critical factor. This observation is consistent with previous reporting (e.g. Humphrey \& Wechsler, 2007; Douglas, 2012) of variation in outcomes within different types of PSTE programme. The framework for analysis developed in this study might be used in a larger study that has the power to detect whether the patterns suggested by these results are found more generally. This study directs attention towards dimensions of PSTs' school experience which could be critical to the way they approach their own learning.

\section{Conclusion}

This paper adopts a phenomenographic/variation theory perspective to provide some new insights into PSTs' conceptions of their own learning and the influence of the contexts provided by pre-service teacher education for developing these conceptions. We believe these insights are valuable for policy and practice in teacher education in many countries. Our analysis found that PSTs' conceptions of their own learning varied in terms of beliefs about knowledge for teaching and three related components of reflection: focus, timing and self-determination. Each of these was analysed as a distinct phenomenon and the study suggests dimensions of variation within these conceptions that should be helpful when planning programmes for developing new teachers. The study also adds to an emerging literature in PVT investigating relationships between conceptions of distinct phenomena. In this study we observe each of the four phenomena (beliefs about knowledge for teaching, focus, timing and self-determination in reflection) as forming together a 'meta-phenomenon' of learning to become a teacher. The study makes a tentative suggestion of two conceptions of this meta-phenomenon: 'adherence' or 'enquiry'. We associate the 'adherence' conception with the way in which teaching has been framed by recent policy in England. We associate the 'enquiry' conception with the ideas of 'teachers as professional' that have been articulated by academics in teacher education. We found that shifts from one of these conceptions to another were more strongly associated with PSTs' experience of mentoring in school than whether they were enrolled on a university-led or schoolled ITE programme. The sample does draw from the range of routes into teaching created by recent policy in England and Wales. Therefore, we stood a reasonable chance of capturing the spread of conceptions that PSTs may adopt. Nevertheless, this was a small-scale study and there may be other ways that PSTs may develop when learning in other contexts and further studies are needed to examine the usefulness of the categorical distinctions suggested by this research. Moreover, there will be other 
school-led and HE-led programmes where the balance and nature of school/HEI experiences will be different from those of the PSTs in this study.

Further research would be useful as the evidence in this study points towards some important implications for routes into teaching. One implication is that nature of school mentoring is hugely important for the way PSTs understand and conduct their learning. It is very difficult for a lead institution to shape PSTs' learning if this is out of line with expectations in the school in which they are gaining their experience. Second, 'being reflective' is widely spoken of as a hallmark of effective practice in becoming a teacher. However, we identified critical differences in the focus, timing and self-determination of PSTs' reflection. Nonetheless, whilst each of the routes into teaching in our study expected PSTs to reflect on their teaching experience, none explicitly distinguished between reflection on events, themes or being a teacher. In our review of PSTs' written reflections, we noted that reflections were shallow when limited to specific events, without placing these in the context of a theme or what it meant to be a teacher. Therefore, we believe that the dimensions of variation in PSTs' conceptions that we have identified could provide school mentors and university tutors with a way of helping PSTs to become more aware of how they might to improve their learning to become teachers.

\section{References}

Authors [1] to [4]

Åkerlind, G. S. (2003). Growing and developing as a university teacher - variation in meaning. Studies in Higher Education, 28(4), 375-390. DOI: 10.1080/0307507032000122242

Ballou, D. \& Podgursky, M. (1998). The case against teacher certification. The Public Interest, 132(2), 17-29.

BERA (British Educational Research Association) (2011). Ethical guidelines for educational research. Retrieved from https://www.bera.ac.uk/researchersresources/resources-for-researchers

Boyd, D.J., Grossman, P., Lankford, H., Loeb, S., Micheli, N.M. \& Wyckoff, J. (2006). Complex by Design: Investigating pathways into teaching in New York City Schools, Journal of Teacher Education, 55(2), 155-166.

Buitink, J. (2009). What and how do student teachers learn during school-based teacher education. Teaching and Teacher Education, 25(1), 118-127.

Carter, A. (2015) Carter review of initial teacher training (ITT), London: Department for Education.

Chan, K. (2003). Hong Kong teacher education students' epistemological beliefs and approaches to learning. Research in Education 69(1), 36-50. 
Chan, K. W. (2011). Preservice teacher education students' epistemological beliefs and conceptions about learning. Instructional Science, 39(1), 87-108.

Chan, K. W. \& Elliott, R. G. (2004). Relational analysis of personal epistemology and conceptions about teaching and learning. Teaching and Teacher Education, 20(8), 817831.

Cheng, M. M., Chan, K. W., Tang, S. Y. \& Cheng, A. Y. (2009). PST education students' epistemological beliefs and their conceptions of teaching. Teaching and Teacher Education, 25(2), 319-327.

Cochran-Smith, M., \& Lytle, S. L. (1999). Relationships of knowledge and practice: Teacher learning in communities. Review of Research in Education, 24, 249-305.

Colucci-Gray, L., \& Fraser, C. (2008). Contested aspects of becoming a teacher: Teacher learning and the role of subject knowledge. European Educational Research Journal, 7(4), 475-486.

Conway, P. F., Murphy, R., Rath, A. \& Hall, K. (2009). Learning to teach and its implications for the continuum of teacher education: A nine-country cross-national study. Report Commissioned by the Teaching Council: Ireland. Cork, University College Cork.

Dahlberg, G., Moss, P., Pence, A. (2007) Beyond Quality in Early Childhood Education and Care: Languages of Evaluation, Oxford: Routledge.

Dahlin, B. \& Watkins, D. (2000). The role of repetition in the processes of memorising and understanding: A comparison of the views of German and Chinese secondary school students in Hong Kong. British Journal of Educational Psychology, 70(1), 65-84.

Department for Education (2016). Educational Excellence Everywhere, Cm 9230. London, Department for Education.

Douglas, A. S. (2012). Capturing the object of initial teacher education by studying tools-in-use in four school subject departments. Research Papers in Education, 27(3), 285302.

Durden, G. (2018). Accounting for the context in phenomenography-variation theory: Evidence of English graduates' conceptions of price. International Journal of Educational Research, 87, 12-21.

Edwards, A., Gilroy, P. \& Hartley, D. (2002) Rethinking teacher education: collaborative responses to uncertainty. London: Routledge Farmer.

Entwistle, N. \& McCune, V. (2004). The conceptual bases of study strategy inventories. Educational Psychology Review, 16(4), 325-345.

Entwistle, N. \& McCune, V. (2013). The disposition to understand for oneself at university: Integrating learning processes with motivation and metacognition. British Journal of Educational Psychology, 83(2), 267-279. 
Furlong, J., Whitty, G., Barrett, E., Barton, L., \& Miles, S. (1994). Integration and partnership in initial teacher education--dilemmas and possibilities. Research Papers in Education, 9(3), 281-301.

Flick, U. (2002) An Introduction to Qualitative Research, London, Sage Publications.

Gelfuso, A., \& Dennis, D. V. (2014). Getting reflection off the page: The challenges of developing support structures for pre-service teacher reflection. Teaching and Teacher Education, 38, 1-11.

Gilroy, P. (1993). Back to the future: the de-professionalisation of initial teacher education in England and Wales. Australian Journal of Teacher Education, 18(2), 5-14. http://dx.doi.org/10.14221/ajte.1993v18n2.2

Goodnough, K., Pelech, S. \& Stordy, M. (2014). Effective Professional Development in STEM Education: The Perceptions of Primary Elementary Teachers. Teacher Education and Practice, 27(2/3), 402-423

Gordon, C. \& Debus, R. (2002). Developing deep learning approaches and personal teaching efficacy within a preservice teacher education context. British Journal of Educational Psychology, 72(4), 483-511.

Gove, M. (2010). Michael Gove Speech to the National College Annual Conference, Birmingham. $16^{\text {th }} \quad$ June, $2010 . \quad$ Accessed from https://www.gov.uk/government/speeches/michael-gove-to-the-national-collegeannual-conference-birmingham, 17 $7^{\text {th }}$ January, 2018.

Grindstaff, K., Cho, I. Y. \& Anderson, C. W. (2003). Learning from Field Experiences: Teacher Candidates' Goals and Practices. Annual Meeting of the National Association for Research in Science Teaching, Philadelphia, March 23-6, 2003.

Heikkilä, A. \& Lonka, K. (2006). Studying in higher education: students' approaches to learning, self-regulation, and cognitive strategies. Studies in Higher Education, 31(1), 99-117.

Hordern, J. (2014) 'The logic and implications of school-based teacher formation', British Journal of Educational Studies, 62 (3), 231-248.

Humphrey, D.C., \& Wechsler, D.E. (2007). Insights into Alternative Certification: Initial Findings From a National Study, Teachers College Record, 109(3), 483-530. Hurworth, R. (2012) Techniques to assist with interviewing. In Arthur, J., Waring, M., Coe, R., and Hedges, L. (Eds.), Research methods and methodologies in education (pp. 177185). London: Sage.

Kember, D., Jamieson, Q. W., Pomfret, M. \& Wong, E. T. T. (1995). Learning approaches, study time and academic performance. Higher Education 29(3), 329-343.

Kember, D. \& Leung, D. Y. (1998). The dimensionality of approaches to learning: An investigation with confirmatory factor analysis on the structure of the SPQ and LPQ. British Journal of Educational Psychology, 68(3), 395-407. 
Kremer-Hayon, L. \& Tillema, H. H. (1999). Self-regulated learning in the context of teacher education. Teaching and Teacher Education, 15(5), 507-522.

Krumpal, I. (2013) Determinants of social desirability bias in sensitive surveys: a literature review. Quality and Quantity, 47(4), 2025-2047.

Kyndt, E., Dochy, F., Struyven, K. \& Cascallar, E. (2011). The direct and indirect effect of motivation for learning on students' approaches to learning through the perceptions of workload and task complexity. Higher Education Research E Development 30(2), 135-150.

Linder, C., \& Marshall, D. (2003). Reflection and phenomenography: Towards theoretical and educational development possibilities. Learning and Instruction, 13(3), 271-284.

Marton, F. (2015). Necessary conditions of learning. London, Routledge.

Marton, F., \& Booth, S. (1997). Learning and awareness. Mawah., NJ., Lawrence Erlbaum.

Marton, F., \& Pong, W. Y. (2005). On the unit of description in phenomenography. Higher Education Research E Development, 24(4), 335-348.

Marton, F. \& Säljö, R. (1976). On qualitative differences in learning: I-Outcome and process. British Journal of Educational Psychology, 46(1), 4-11.

McIntyre, J., Youens, B., \& Stevenson, H. (2019). Silenced voices: The disappearance of the university and the student teacher in teacher education policy discourse in England. Research Papers in Education, 34(2), 153-168.

McLeskey, J. \& Waldron, N. L. (2004). Three conceptions of teacher learning: Exploring the relationship between knowledge and the practice of teaching. Teacher Education and Special Education: The Journal of the Teacher Education Division of the Council for Exceptional Children, 27(1), 3-14.

Oosterheert, I.E., Vermunt, J. D. \& Denessen, E. (2002). Assessing orientations to learning to teach. British Journal of Educational Psychology 72(1), 41-64.

Pang, M. F. (2003). Two faces of variation: On continuity in the phenomenographic movement. Scandinavian Journal of Educational Research, 47(2), 145-156.

Pang, M. F. \& Marton, F. (2003). Beyond 'lesson study": Comparing two ways of facilitating the grasp of some economic concepts. Instructional Science, 31(3), 175-194.

Qu, S. Q. \& Dumay, J. (2011). The qualitative research interview. Qualitative Research in Accounting $\mathcal{E} \quad$ Management, 8(3), 238-264. http://dx.doi.org/10.1108/11766091111162070

Ryan, R.M. \& Deci, E. L. (2000). Self-determination theory and the facilitation of intrinsic motivation, social development and well-being. American Psychologist, 55(1), $68-78$. 
Schommer, M. (1994). Synthesizing epistemological belief of research: tentative understandings and provocative confusions. Educational Psychology Review, 6(4), 293319.

Sing Chai, C., Teo, T. \& Beng Lee, C. (2009). The change in epistemological beliefs and beliefs about teaching and learning: A study among PSTs. Asia-Pacific Journal of Teacher Education, 37(4), 351-362.

Struyven, K., Dochy, F., Janssens, S. \& Gielen, S. (2006). On the dynamics of students' approaches to learning: The effects of the teaching/learning environment. Learning and Instruction, 16(4), 279-294.

Tait, H., Entwistle, N. J. \& McCune, V. (1998). ASSIST: A reconceptualisation of the approaches to studying inventory. In Rust. C. (Ed.) Improving student learning: Improving students as learners. Oxford, The Oxford Centre for Staff and Learning Development.

Taylor, A. (2008). Developing understanding about learning to teach in a universityschools partnership in England. British Educational Research Journal, 34(1), 63-90.

Trigwell, K., Prosser, M. \& Waterhouse, F. (1999). Relations between teachers' approaches to teaching and students' approaches to learning. Higher Education, 37(1), 57-70.

Van Petegem, P., Donche, V. \& Vanhoof, J. (2005). Relating PSTs' approaches to learning and preferences for constructivist learning environments. Learning Environments Research, 8(3), 309-332.

Yau, C. W. (1996). PSTs' views of mentoring in physical education. In M. Mawer (ed.) Mentoring in physical education: issues and insights, 108-120. London, The Falmer Press.

Wright, N. \& Bottery, M. (1997). Perceptions of Professionalism by the Mentors of Student Teachers. Journal of Education for Teaching 23 (3): 235-252.

doi:10.1080/02607479719981. 


\section{Note}

${ }^{1}$ In terms of the diagrammatic representation of demand and supply this is the difference between shifts in the demand or supply curves (as presented in Pang and Marton, 2005) and the effect of price on supply or demand as shown by the shape or elasticity of each curve. An equivalent table to Table 1 but for the Pang \& Marton (2003) study would be:

\section{Dimensions of variation in conceptions of the incidence of a sales tax}

\begin{tabular}{l|cccc}
\hline \multirow{2}{*}{ Conception } & \multicolumn{3}{|c}{ Dimensions of variation } \\
\cline { 2 - 5 } & $\begin{array}{c}\text { Power of } \\
\text { sellers }\end{array}$ & $\begin{array}{c}\text { Elasticity of } \\
\text { Demand }\end{array}$ & $\begin{array}{c}\text { Elasticity } \\
\text { of } \\
\text { Supply }\end{array}$ & Price \\
\hline $\begin{array}{l}\text { 1 Sales tax added to price due to the market } \\
\text { powers of sellers }\end{array}$ & $v$ & $i$ & $i$ & $v$ \\
2 Sales tax on top of price due to inelastic & $i$ & $v$ & $i$ & $v$ \\
demand & $i$ & $v$ & $i$ & $v$ \\
3 Sales tax shared due to elastic demand & $i$ & $i$ & $v$ & $v$ \\
4 Sales tax shared due to elastic supply & $i$ & $v$ & $v$ & $v$ \\
Sales tax shared due to elastic demand and & $i$ & & & \\
$\quad$ supply & & & & \\
\hline
\end{tabular}

Although this is a study of the burden of tax, the pupil responses used to illustrate each category refer to the extent to which the rise in price is affected by elasticity of demand and supply. They do not reason in terms of $P X Q$ in the distribution of the tax burden. 